\title{
Erken Çocukluk Döneminde Travmatik Diş Yaralanmalarının, Maloklüzyonların ve Diş Çürüğünün Ağız Sağlı̆ı ile İlişkili Yaşam Kalitesi Üzerine Etkisi
}

\author{
Aliye Tuğçe Gürcan(0000-0002-8444-1780) ${ }^{\alpha}$, Mine Koruyucu(0000-0002-2077-5095) ${ }^{\beta}$, Merve Bayram(0000-0002-8440-367X) ${ }^{\nu}$, \\ Figen Seymen(0000-0001-7010-2035) ${ }^{\beta}$ \\ Başvuru Tarihi: 05 Ağustos 2020
}

Selcuk Dent J, 2021; 8: 467-476 (Doi: 10.15311/selcukdentj.696476) Yayına Kabul Tarihi: 02 Ocak 2021

Öz

Erken Çocukluk Döneminde Travmatik Diş Yaralanmalarının, Maloklüzyonların ve Diş Çürüğünün Ağız Sağlığı ile Ilişsili Yaşam Kalitesi Üzerine Etkisi

Amaç: Bu çalışmanın amacı, travmatik diş yaralanmalarıın (TDY) ve diş çürüğünün okul öncesi çocukların Ağız Sağlığı ile Illişkili Yaşam Kalitesi (OHRQoL) üzerindeki etkisini değerlendirmektir.

Gereç ve Yöntemler: Ağız Sağlığı ile İlişkili Yaşam Kalitesini ölçmek için 206 okul öncesi çocuğun velisine 13 soruluk Erken Çocukluk Çağı Ağız Sağığı Etki Ölçeği (ECOHIS) uygulanmıştır. Çocukların travmatik diş yaralanmaları, diş çürüğü (dmft skorları) ve ön bölge maloklüzyon özelliklerine bakılmıştır.

Bulgular: Çocukların yaş ortalaması $4.09 \pm 0.97$ bulunmuştur. Diş çürüğü, Ağız Sağlığı ile iliş̧kili Yaşam Kalitesi üzerinde olumsuz bir etki göstermiştir. Diş çürüğü; Ağız Sağlığı ile ilişkili Yaşam Kalitesi ortalaması, semptomları, fonksiyonu, psikolojisi, ailesel sıkıntı ve aile fonksiyon alanları üzerinde olumsuz bir etki göstermiştir. Ön bölgede maloklüzyon varlığı sadece sosyal etkileşim alanı üzerinde olumsuz bir etki göstermiştir. Komplike travmatik diş yaralanmaları, komplike olmayan travmatik dis yaralanmalarına göre semptomlar açısından daha olumsuz bir etki göstermiştir.

Sonuç: Travmatik dental yaralanma ve maloklüzyon gözlenen dişin varığı, okul öncesi çocukların Ağız Sağlığı ile Illişkili Yaşam Kalitesi üzerinde yalnızca çocuk alanında olumsuz bir etkiye sahiptir; ancak, diş çürüğü, hem çocuk alanında hem aile alanında Ağız Sağlığı ile iliş̧kili Yaşam Kalitesi ile güçlü bir ilişkiye sahiptir.

\section{ANAHTAR KELIMELER}

Ağız sağlığı ile ilişkili yaşam kalitesi, Dental travma, Diş çürüğü, Erken çocukluk çağı ağız sağlığı etki ölçeği, Okul öncesi çocuklar

Ağız Sağlığı ile İlişkili Yaşam Kalitesi (OHRQoL) kavramı, ağız sağlığı ya da hastalığının kişisel günlük işleyiş, genel sağlık ya da genel yaşam kalitesi üzerindeki etkisine karşılık gelmektedir. ${ }^{1}$

Tıpın diğer branşlarında olduğu gibi diş hekimliğinde de, mevcut hastalığın objektif olarak değerlendirilebilmesi için, ağız sağlığı ölçümleri dışında, yaşam kalitesi üzerine etkisinin de hesaba katılması gerektiği fark edilmiştir. $^{2}$

Yaşam kalitesinin değerlendirilmesi, diş hekimliğinin

\section{ABSTRACT}

Effects of Traumatic Dental Injuries, Malocclusions and Dental Caries on Oral Health-Related Quality of Life in Early Childhood

Background: The aim of this study was to assess the effect of traumatic dental injuries and dental caries on the Oral HealthRelated Quality of Life (OHRQoL) of preschool children.

Methods: The 13 questions and six domains of Early Childhood Oral Health Impact Scale (ECOHIS) were administered to 206 preschool children's parents to measure Oral Health-Related Quality of Life. Type of traumatic dental injuries, dental caries (dmft scores), and anterior malocclusions traits of the children were recorded after the oral examination.

Results: The children's mean age was $4.09 \pm 0.97$. Dental caries showed a negative impact on the overall Oral Health-Related Quality of Life mean and symptoms, function, psychological, parental distress, and family function domains. The presence of anterior malocclusion traits showed a negative effect only on the social interaction domain. Complicated traumatic dental injuries showed a negative effect on symptoms domain than uncomplicated traumatic dental injuries.

Conclusion: Having a tooth with traumatic dental injuries and malocclusions have a negative impact on the Oral HealthRelated Quality of Life of preschool children only one domain (child domain), although dental caries, has a strong association (child domain + family domain) with the Oral HealthRelated Quality of Life of preschool children and their parents.

\section{KEYWORDS}

Dental caries, Dental trauma, Early childhood oral health Impact scale, Oral health-related quality of life, Preschool children

önemli bir parçası olmuştur. Fiziksel, zihinsel ve sosyal özellikler, sağlık bileşenlerinde bir arada bulunmaktadır. Bu nedenle, ağız sağlığı belirteçleri, hastalığın ve tedavinin psikolojik ve sosyal etkilerini de ölçerek değerlendirilmelidir. ${ }^{3,4}$

Maloklüzyon da dahil olmak üzere ağız sağlığını etkileyen durumlar oldukça yaygındır ve sadece fiziki ve ekonomik durumu değil, aynı zamanda fonksiyonu, görünüşü, kişiler arası ilişkileri, benlik saygısını ve psikolojik iyi oluşu etkileyerek yaşam

\footnotetext{
${ }^{\alpha}$ Altınbaş Üniversitesi Diş Hekimliği Fakültesi Çocuk Diş Hekimliği AD. İstanbul, Türkiye

$\beta$ İstanbul Üniversitesi Diş Hekimliği Fakültesi Çocuk Diş Hekimliği AD. İstanbul, Türkiye

${ }^{v}$ İstanbul Medipol Üniversitesi Diş Hekimliği Fakültesi Çocuk Diş Hekimliği AD. İstanbul, Türkiye
} 
kalitesini bozabilmektedir. $^{5}$ Tedavi ihtiyacını belirlemeye yönelik indeksler, yalnızca mevcut durumu ortaya koymakta, ancak bu durumun hastanın yaşam kalitesine etkisini ölçmemektedir. ${ }^{6}$ Bunu değerlendirebilmek amacıyla geliştirilen OHRQoL kavramı, bireyin ağız sağlığı, fonksiyonel ve duygusal iyilik hali, beklentileri, memnuniyeti ve benlik duygusunun öznel bir değerlendirmesini içeren çok boyutlu bir yapıdan oluşmaktadır ve Dünya Sağlık Örgütü (DSÖ) tarafından Küresel Ağız Sağlığ Programı'nın önemli bir bölümü olarak kabul edilmektedir. ${ }^{7}$

Günümüzde, çocuk hastaların OHRQoL ilişkisini değerlendirebilmek için, dental anamnez elde edilirken, ebeveynlerden alınan bilgilerin yanı sıra, çocuklarla iletişim kurularak elde edilen bilgilere de dikkat edilmesi gerektiği tavsiye edilmiştir. ${ }^{8}$ Ayrıca, diş hastalıkları ve dental tedavi deneyiminin, okul öncesi çağındaki çocukların ve onlara bakım veren kişilerin (veli, bakıcı) ağız sağlığı ile ilgili yaşam kalitesini olumsuz etkileyebileceği düşüncesiyle, Erken Çocukluk Çağı Ağız Sağlığı Etki Ölçeği (ECOHIS) adı verilen bir ölçek de geliştirilmiştir. ${ }^{4}$ Diş tedavisi, sadece ağız sağlığını iyileştirmek için değil, aynı zamanda yaşam kalitelerinin iyileştirilmesini teşvik etmek için bu hastalar üzerinde olumlu bir psikososyal etki sağlayabilmektedir. ${ }^{8}$

Eskiden biberon çürüğü olarak adlandırılan erken çocukluk çağı çürükleri (ECC) önemli bir halk sağlığı sorunu olmaya devam etmektedir. ECC, altı yaşın altındaki çocukların süt dişlerinde bir ya da daha fazla sayıda çürük (kavitesiz ya da kaviteli lezyonlar), kayıp diş (çürük nedeniyle), ya da dolgulu diş yüzeylerinin varlığının görülmesi durumu olarak tanımlanmıştır. ECC'nin sonuçları genellikle süt ve sürekli dişlenmede yüksek riskte yeni çürük oluşumu, acil ziyaretleri ve hastane yatışları, yüksek tedavi maliyetleri, kayıp okul günleri, öğrenme yeteneğinde düşüş ve OHRQoL'nin azalması olarak belirtilmiştir. Amerikan Pediatrik Diş Hekimliği Akademisi (AAPD), ECC'yi çoklu risk ve koruyucu faktörlerinin uzun süren dengesizliğine maruz kalma sonucu oluşan önemli bir kronik rahatsızlık olarak tanımlamıştır. ${ }^{9}$ Geniş kavitasyonlu ECC lezyonları, tedavi açısından zorluk teşkil etmektedir. Hastanın çok genç yaşı nedeniyle sedasyon stratejilerinin kullanımının kontrendike olabileceği ve diğer davranışsal yönlendirme tekniklerinin başarısızlığı göz önüne alındığında, ECC oluşumunu engellemenin önemli olduğu belirtilmiştir. Optimum tedavi koşullarında ve genel anestezi altında tedavi edilen ECC olgularında bile, tekrarlayan çürükler görülebilmektedir. Bu nedenle diş kaybını önleyen koruyucu önlemlerin alınması, pozitif rehabilitasyon çıktılarının elde edilmesi ve kontrol randevularının düzenli olarak yapılması gerekliliği vurgulanmıştır. ${ }^{10}$

Biyolojik ya da klinik değişkenler ile sağlıkla ilgili yaşam kalitesi arasındaki ilişkiler, çeşitli kişisel, sosyal, çevresel ve kültürel durumların aracılık ettiği bir durumdur. Önceki çalışmalarda travmatik diş yaralanmalarının (TDY) genç erişkinlerde biyolojik, duygusal ve psikososyal etkileri olduğu sonucuna varılmıştır. ${ }^{11-13}$ TDY'nin tedavi edilmesi, etkilenen çocukların yaşam kalitesini arttırabilir. Tedavi edilmeyen diş yaralanmalarının, çocukların yaşam kalitesi üzerinde negatif etkisinin görülmesi olasılığının, tedavi edilmeyen dişler ve yapılmayan restorasyonlara göre daha yüksek olduğu belirtilmiştir. Kuron restorasyonlarının, yaşam kalitesinin sosyal yönlerinde bir iyileşmeye katkıda bulunduğu, ancak TDY'nin çocukların yaşam kalitesi üzerindeki olumsuz etkisini tamamen ortadan kaldırmadığı bildirilmiştir. ${ }^{11}$

Üst santral kesici dişler travma ile daha sık etkilenen dişlerdir, ağızdaki pozisyonları nedeniyle, diğer dişlere göre daha az korunmaktadırlar. Artan insizal overjet ve ön açık kapanışın varlığı, TDY'nin predispozan faktörleri olarak bildirilen fiziksel özelliklerdir. Ayrıca, bu ön bölge maloklüzyon özelliklerinin varlığı, işlev kaybına ve estetik sorunlarına neden olabilmektedir. ${ }^{12}$

$\mathrm{Bu}$ çalışmanın amacı, TDY, maloklüzyon ve diş çürüğünün, okul öncesi çocukların OHRQoL üzerindeki etkisini değerlendirmektir.

\section{GEREÇ VE YÖNTEMLER}

Bu çalışma için İstanbul Üniversitesi Tıp Fakültesi Etik Kurulu'ndan etik kurul onayı alınmıştır (No:2014/276). Üniversite çocuk diş hekimliği kliniğine Kasım 2014 Şubat 2015 tarihleri arasında başvuran 2-5 yaş arası sistemik olarak sağlıklı toplam 206 çocuk randomize olarak çalışmaya dahil edilmiştir. Helsinki Bildirgesi' ne uygun olarak, hastalar ve aileleri bilgilendirilmiş ve ebeveynler tarafından imzalanmış Bilgilendirilmiş Gönüllü Onam Formu alınmıştır. Bu prosedürlere uygun olarak alınan onamlardan sonra hastaların, ayna, sond ve reflektör ışığı altında dental muayenesi yapılmıştır.

Bu çalışmada Pahel ve arkadaşlarının çalışması ${ }^{5}$ örnek alınarak, Juniper ve arkadaşları ${ }^{14}$ tarafından tanımlanan sağlıkla ilgili yaşam kalitesi araçlarının geliştirilmesi ve test edilmesi için kullanılan metodoloji, Guyatt ve arkadaşları $^{15}$ ile DeVellis ${ }^{16}$ tarafından tanımlanan ölçek geliştirme prosedürleri ve Abanto ve arkadaşları ${ }^{11}$ tarafından geliştirilen Travma ve ECOHIS formu (ECC muayene bilgilerini içeren) kullanılmıştır. Ağız sağlığı ile ilgili yaşam kalitesini ölçmek için 206 adet okul öncesi çocuğun velilerine 13 soruluk ölçeğin Türkçe versiyonu uygulanmıştır. ${ }^{17}$ Ağız içi muayenede diş çürüğü (dmft skoru), TDY'nin tipi ve ön bölge maloklüzyon varlığı kaydedilmiştir. TDY; Andreasen Sınıflaması esas alınarak komplike ve komplike olmayan olmak üzere ikiye ayrılmıştır. ${ }^{18}$ Komplike TDY; pulpanın açıkta olduğu, dişin renkleştiği, komplike kuron kırıkları, kök kırıkları, lateral lüksasyon, ekstruziv lüksasyon, intrüziv lüksasyon ve avülsiyonu içermektedir. Komplike olmayan TDY ise sadece diş renkleşmesinin meydana geldiği, pulpanın açıkta olmadığı, mine ile sınırlı kuron kırığı, mine-dentin ile 
sınırlı kuron kırığı, sarsılma ve sublüksasyonu içermektedir. Ön bölge maloklüzyon muayenesinde ise openbite ve overjet varlığı değerlendirilmiştir. Diş çürüğü alanında d (çürük diş sayısı), m (çürük ya da başka bir sebeple kaybedilmiş diş sayısı), f (dolgulu diş sayısı) kodları kullanılmıştır. Dmft değeri 1-5 arasında ise düşük, 6 ve üzerinde ise yüksek olarak değerlendirilmiştir. (Resim 1) ${ }^{11}$ Hastaları muayene eden araştırma ekibi, değerlendirme skorlarının objektif olması amacıyla, önceden verilen bir eğitim almış ve sonrasında karşılaştırmalı ortak değerlendirmelerle kalibre edilmiştir. İki araştırıcının muayene içi kappa değerleri 0,90 olarak belirlenmiştir. Anket formunun çocuk etki alanında (ilk 9 soru), çocuk üzerine etkiler; aile etki alanında (son 4 soru) ise aile üzerine etkiler ile ilgili sorular bulunmaktadır (Resim 2).

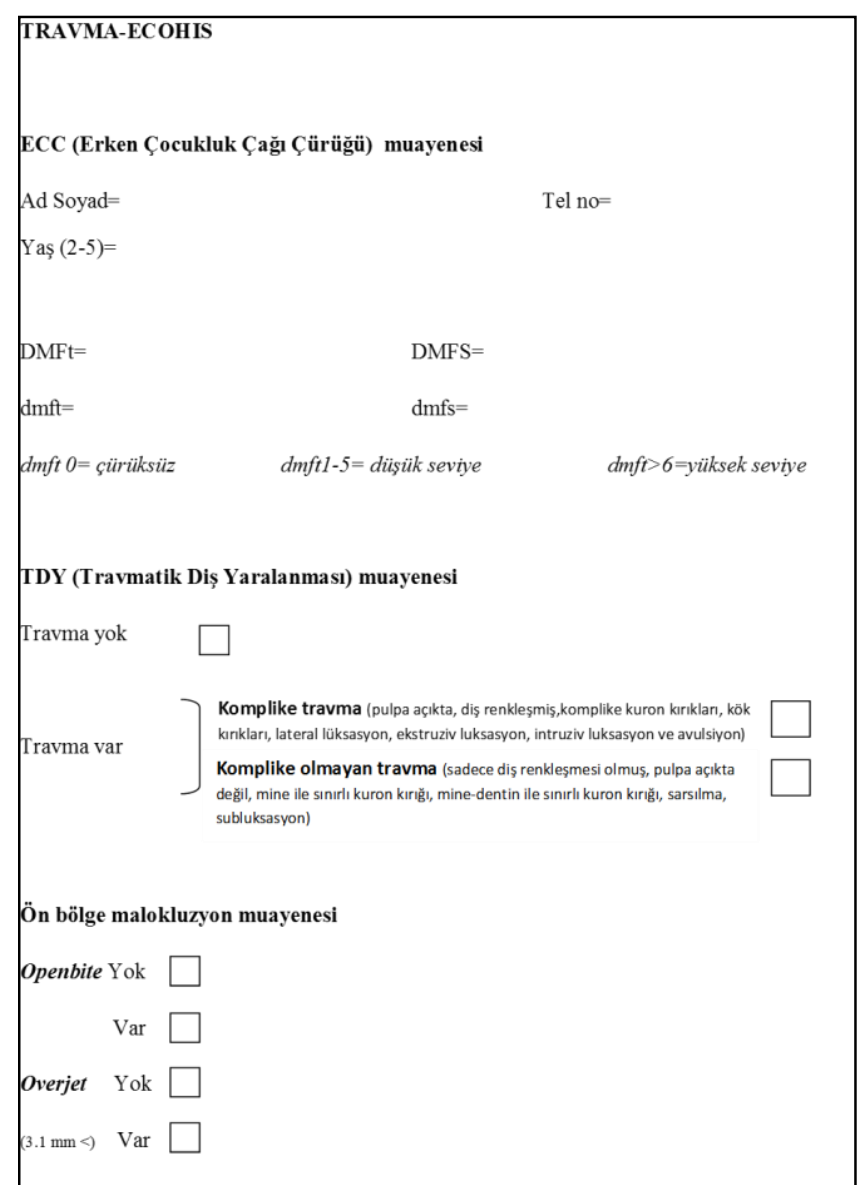

Resim 1

Diş Çürüğ̈, Travmatik Dental Yaralanmalar ve Ön Bölge Maloklüzyon durumu ile ilgili Anamnez Formu

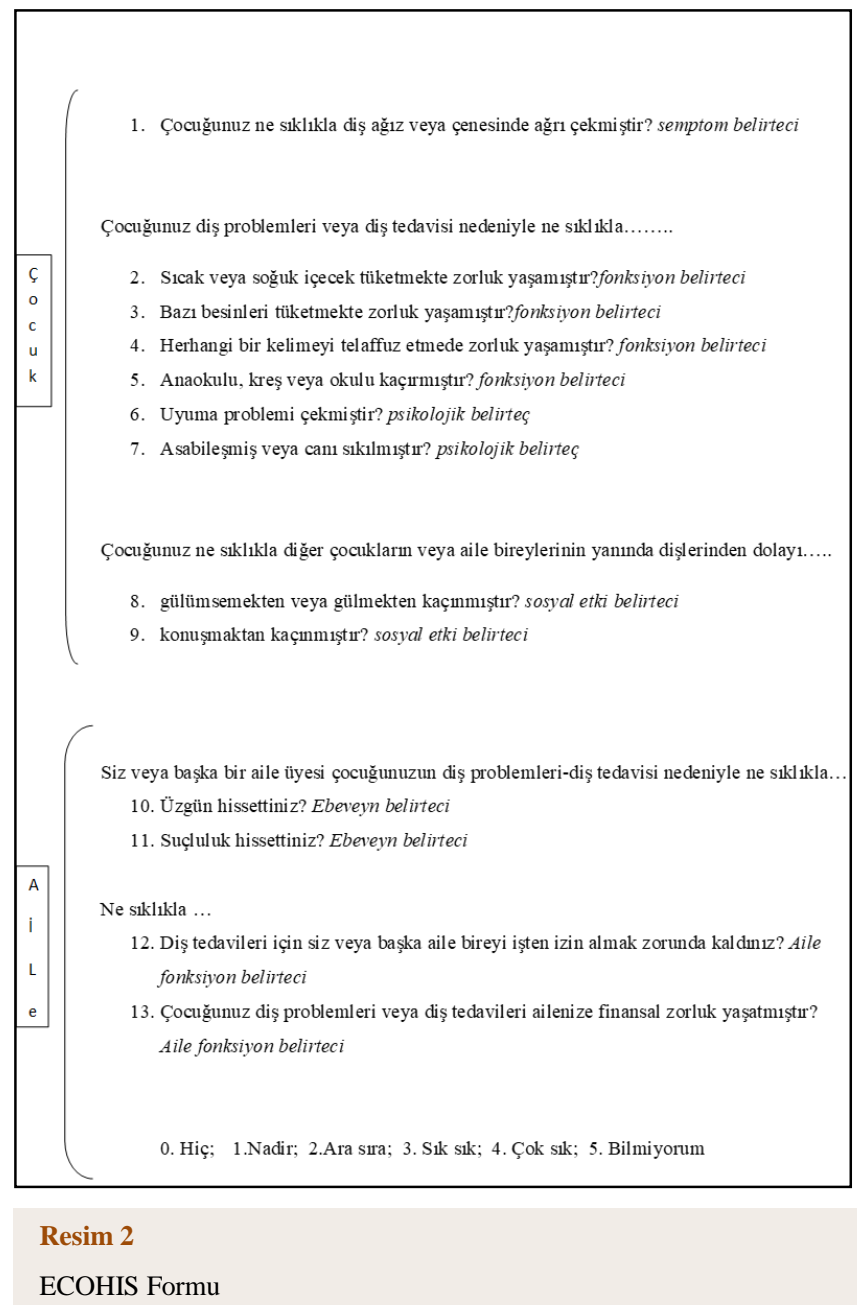

Sorulara verilen yanttlar; hiç ( 0 puan), nadir (1 puan), ara sıra (2 puan), sık sık (3 puan), çok sık (4 puan) ve bilmiyorum (5 puan) olarak derecelendirilmiştir. Her bir derece, puan karşlığını içermektedir ve yüksek puanlar, TDY üzerindeki etkilerin olumsuz olduğunu ya da artmış olduğunu; düşük puanlar ise olumlu ya da azalmış etkiyi belirtmektedir (Çocuk etki alanı ve aile etki alanı için ayrı ayrı değerlendirilmiştir.) Bilmiyorum olarak verilen yanıtlar sayılmış ancak total ECOHIS skorundan çıkarılmıştır. Hesaplamalarda, daha önceki yayınlarda kullanılan yöntemler örnek alınmıştı. ${ }^{3,6,19}$ Çocuk etki alanında yanıtlanmamış iki ya da daha fazla soru varsa, aile etki alanında yanıtlanmamış bir ya da daha fazla soru varsa, mevcut form analize dahil edilmemiştir.

Bulgular değerlendirilirken istatistiksel analiz için SPSS (Statistical Package for Social Sciences) Release 20.0 kullanılmıştır. Verilerin değerlendirilmesinde tanımlayıcı istatistiksel metodlar (standart sapma, frekans, ortalama) ve Ki-Kare testi kullanılmıştır. Bulgular, $p<0.05$ anlamlılık düzeyinde değerlendirilmiştir. 


\section{BULGULAR}

Çalışmaya dahil edilen toplam 206 çocuğun 106'sı kız (\%51.45), 100'ü (\%48.54) erkektir (Grafik 1).

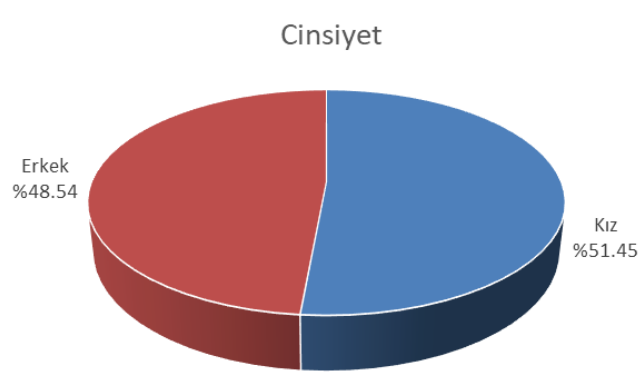

- Kı - Erkek

Grafik 1

Cinsiyet Dağılımı

Çalışmaya dahil edilen çocukların yaş dağılımları grafiğine bakıldığında (Grafik 2), çocukların 14 tanesinin (\% 6.79) 2 yaşında, 41 tanesinin (\% 19.92 ) 3 yaşında, 64 tanesinin (\%31.06) 4 yaşında ve 87 tanesinin (\% 42.23) 5 yaşında olduğu görülmektedir. Çocukların yaş ortalaması $4.09 \pm 0.97$ bulunmuştur.

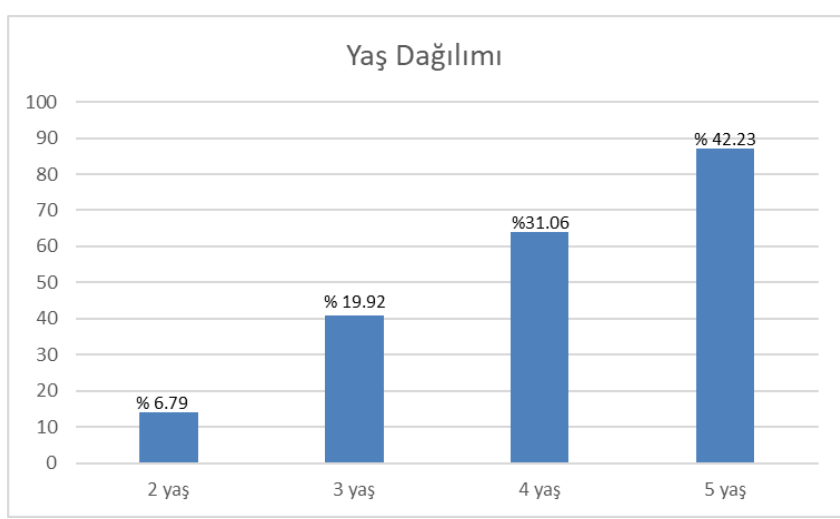

Grafik 2

Yaş Dağılımı

Anketi yanitlayan velilerin \% 92' si annelerden, \% 8' i ise baba, dede, anneanne, babaanne ve diğer bakımla ilgilenen kişilerden oluşmaktadır. Annelerin \% 75' $\mathrm{i}$ ise ev hanımıdır.

Grafik 3' te, ECOHIS anketi sorularına velilerin verdiği yanıtların yüzdeleri görülmektedir.
1. Cocuğunuz ne s1klikla diş ağız veya çenesinde ağrı çekmiştir?

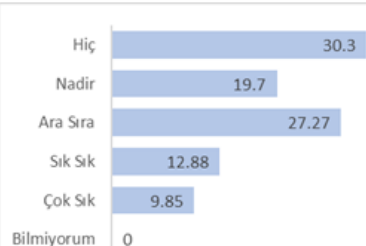

Çocuğunuz diş problemleri veya diş tedavisi nedeniyle ne skllkla...

2. Soru: Sicak veya soğuk içecek tüketmekte zorluk yaşamıştır?
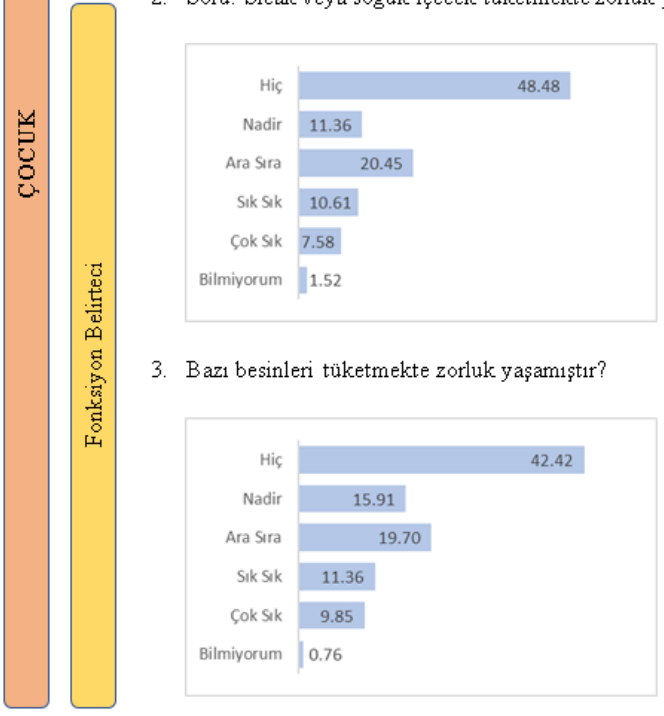

3. Bazı besinleri tüketmekte zorluk y aşamıştır?
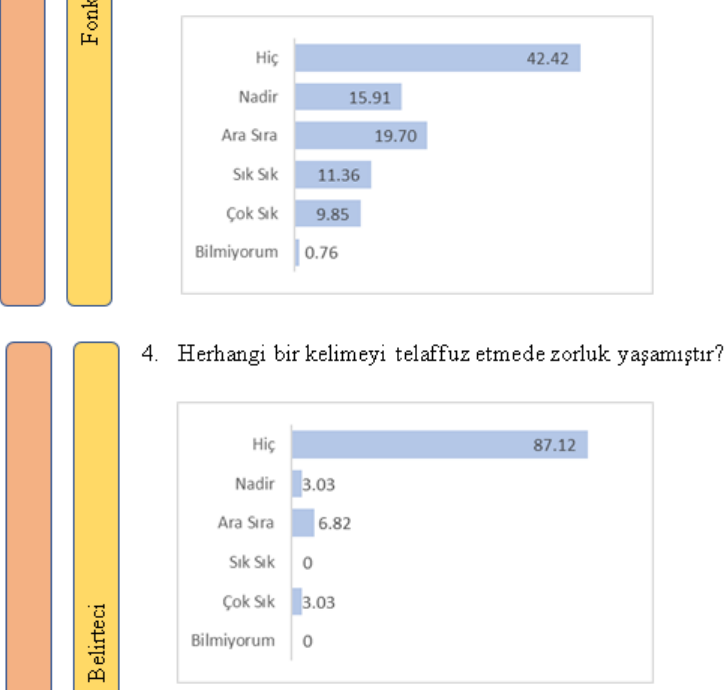

5. Anaokulu, kreş veya okulu kaçırmıştır?

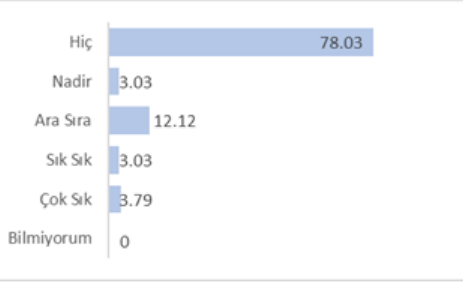

6. Uyuma problemi çekmiştir?

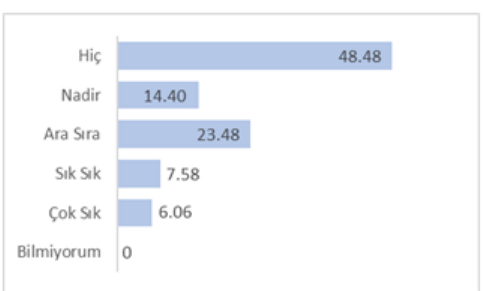

Grafik 3

ECOHIS Anket Cevapları (\%) 

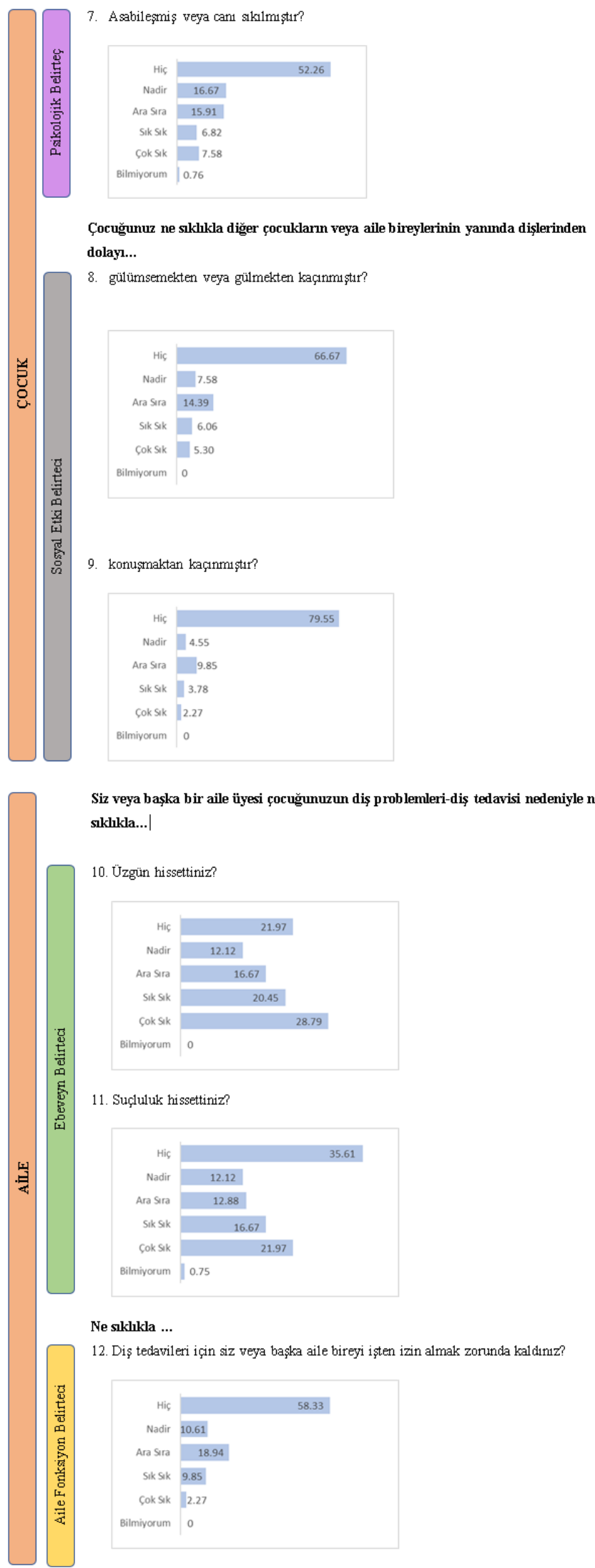

Grafik 3

ECOHIS Anket Cevapları (\%)

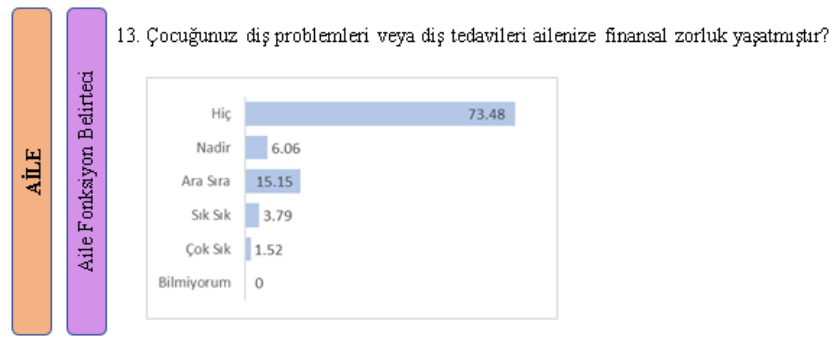

Grafik 3

ECOHIS Anket Cevapları (\%)

Tablo 1'de verilerin gözlemlenen aralık değerleri, ortalama ve standart sapma değerleri görülmektedir. Bu tabloya göre ECOHIS Toplamı medyan değeri 11 ve ortalama değeri $12.95 \pm 10.27$ bulunmuştur. Çocuk etki alanındaki medyan değerlere bakıldığında semptomlar skoru 2, fonksiyon skoru 2, psikolojik skor 1 ve sosyal skor 0 bulunmuştur. Aile etki alanında ailesel sıkıntı ve aile fonksiyonu skorları sırasıyla 4 ve 0 bulunmuştur.

Tablo 1.

Verilerin gözlemlenen aralık değerleri, ortalama ve standart sapma değerleri

\begin{tabular}{|lll|}
\hline ECOHIS & Gözlemlenen Aralık & Ortalama \pm (SS) \\
\hline ECOHIS -Toplam & $0-44$ & $12.95 \pm 10.27$ \\
\hline $\begin{array}{l}\text { Çocuk Etki Alanı } \\
\text { Semptomlar }\end{array}$ & $0-4$ & $1.68 \pm 1.39$ \\
\hline Fonksiyon & $0-16$ & $3.33 \pm 3.67$ \\
\hline Psikolojik & $0-8$ & $1.94 \pm 2.34$ \\
\hline Sosyal Etkileşim & $0-8$ & $1.07 \pm 1.98$ \\
\hline $\begin{array}{l}\text { Aile Etki Alanı } \\
\text { Ailesel Sıkıntı }\end{array}$ & $0-8$ & $3.78 \pm 2.73$ \\
\hline Aile Fonksiyonu & $0-8$ & $1.16 \pm 1.77$ \\
\hline
\end{tabular}

TDY tipi ve her alan için ve toplam ECOHIS için ortalama fark değerleri Tablo 2'de görülmektedir. Komplike TDY, komplike olmayan TDY' ye göre semptomlar açısından daha olumsuz bir etki göstermiştir $(p=0.01)$ (Tablo 2). TDY ile fonksiyon, psikolojik, sosyal etkileşim, ailesel sıkıntı ve aile fonksiyonu skorları karşılaştııılığında komplike ve komplike olmayan TDY arasında istatistiksel olarak anlamlı bir ilişki bulunmamışır ( $p>0.01)$ (Tablo 2). 
Tablo 2.

Travmatik Diş Yaralanması (TDY) tipi ve her alan için ve toplam Erken Çocukluk Çağı Ağız Sağıı̆ı Etki Ölçeği için ortalama fark tablosu

\begin{tabular}{|c|c|c|c|c|}
\hline \multicolumn{4}{|c|}{ TDY Tipi (Ortalama \pm SS ) } & \multirow[b]{2}{*}{$\mathbf{p}$} \\
\hline $\begin{array}{l}\text { ECOHIS } \\
\text { Ölçeği }\end{array}$ & Yok & Komplike TDY & $\begin{array}{l}\text { Komplike } \\
\text { olmayan TDY }\end{array}$ & \\
\hline Semptomlar & $1.91 \pm 1.35(2)$ & $0.87 \pm 1.13(0)$ & $1.00 \pm 1.51(0)$ & $0.001^{* *}$ \\
\hline Fonksiyon & $3.55 \pm 3.66(3)$ & $2.78 \pm 3.79(0)$ & $2.00 \pm 3.21(0)$ & 0.063 \\
\hline Psikolojik & $2.07 \pm 2.31(2)$ & $1.72 \pm 2.49(0)$ & $1.00 \pm 2.32(0)$ & 0.060 \\
\hline $\begin{array}{l}\text { Sosyal } \\
\text { etkileşim }\end{array}$ & $1.00 \pm 1.83(0)$ & $1.24 \pm 2.50(0)$ & $1.50 \pm 2.40(0)$ & 0.600 \\
\hline Ailesel Sıkıntı & $3.75 \pm 2.71(4)$ & $3.33 \pm 2.67(4)$ & $5.21 \pm 2.83(6)$ & 0.090 \\
\hline $\begin{array}{c}\text { Aile } \\
\text { Fonksiyonu }\end{array}$ & $1.25 \pm 1.85(0)$ & $0.87 \pm 1.63(0)$ & $0.78 \pm 0.97(0)$ & 0.490 \\
\hline $\begin{array}{l}\text { ECOHIS- } \\
\text { Skor }\end{array}$ & $13.55 \pm 10.34(12)$ & $10.84 \pm 10.26(9)$ & $11.50 \pm 9.26(9.5)$ & 0.217 \\
\hline
\end{tabular}

Diş çürüğü ve her alan için ve toplam ECOHIS için ortalama fark değerleri Tablo 3' te görülmektedir. Diş çürüğü, OHRQoL üzerinde olumsuz bir etki göstermiştir. Bu olumsuz etki, OHRQoL ortalaması ve semptomları, fonksiyonu, psikolojik, ailesel sıkıntı alanları üzerinde yüksek düzeyde olmak üzere $(p=0.001)$ aile fonksiyonu alanı $(p=0.012)$ üzerinde de istatistiksel olarak anlamlı derecede görülmüştür. (Tablo 3).

Tablo 3.

Diş çürüğü ve her alan için ve toplam Erken Çocukluk Çağı Ağız Sağlığı Etki Ölçeği için ortalama fark tablosu

\begin{tabular}{|c|c|c|c|c|}
\hline \multirow[b]{2}{*}{ ECOHIS } & \multicolumn{3}{|c|}{ dmf-t (Ortalama \pm SS) } & \multirow[b]{2}{*}{$p$} \\
\hline & $\begin{array}{l}\text { Çürük Yok } \\
(\mathrm{dmf}-\mathrm{t}=0)\end{array}$ & $\begin{array}{l}\text { Düşük şiddet } \\
\text { (dmf-t=1-5) }\end{array}$ & $\begin{array}{l}\text { Yüksek şiddet } \\
(\text { dmf-t }>6)\end{array}$ & \\
\hline Semptomlar & $0.18 \pm 0.56(0)$ & $1.38 \pm 1.11(2)$ & $2.37 \pm 1.26(3)$ & $0.001^{* *}$ \\
\hline Fonksiyon & $0.86 \pm 2.28(0)$ & $2.72 \pm 2.77(2)$ & $4.51 \pm 3.98(4)$ & $0.001^{* *}$ \\
\hline Psikolojik & $0.47 \pm 1.58(0)$ & $1.42 \pm 2.01(0)$ & $2.74 \pm 2.42(2)$ & 0.001 ** \\
\hline $\begin{array}{l}\text { Sosyal } \\
\text { etkileşim }\end{array}$ & $0.71 \pm 1.79(0)$ & $0.84 \pm 1.50(0)$ & $1.32 \pm 2.24(0)$ & 0.270 \\
\hline Ailesel Sıkıntı & $1.92 \pm 2.70(0)$ & $3.67 \pm 2.96(4)$ & $4.49 \pm 2.28(4)$ & $0.001^{* *}$ \\
\hline $\begin{array}{l}\text { Aile } \\
\text { Fonksiyonu }\end{array}$ & $0.50 \pm 1.35(0)$ & $1.11 \pm 1.63(0)$ & $1.41 \pm 1.92(0)$ & $0.012^{*}$ \\
\hline ECOHIS-Skor & $4.65 \pm 7.20(0)$ & $11.18 \pm 8.54(11)$ & $16.86 \pm 10.09$ & $0.001^{* *}$ \\
\hline
\end{tabular}

Ön bölge maloklüzyon özellikleri ve her alan için ve toplam ECOHIS için ortalama fark değerleri Tablo 4' te görülmektedir. Ön bölge maloklüzyon özelliklerinin varlı̆ı sadece sosyal etkileşim alanı üzerinde olumsuz bir etki göstermiştir $(p=0.007)$ (Tablo 4). Semptomlar $(p=0.810)$, fonksiyon $(p=0.492)$, psikoloji $(p=0.479)$, ailesel sıkıntı $(p=0.551)$, aile fonksiyonu $(p=0.143)$ alanları ve ECOHIS skoru $(p=0.214)$ üzerinde istatistiksel olarak anlamlı bir etki görülmemiş̧ir $(p>0.01)$.
Tablo 4.

Ön bölge maloklüzyon özellikleri ve her alan için toplam ECOHIS için ortalama fark tablosu

\begin{tabular}{|c|c|c|c|}
\hline \multirow{2}{*}{ ECOHIS } & \multicolumn{2}{|c|}{ Ön Bölge Maloklüzyon Özellikleri (Ortalama \pm SS) } & \multirow{2}{*}{ p } \\
\hline & Var & Yok & \\
\hline Semptomlar & $1.76 \pm 1.55(1.5)$ & $1.67 \pm 1.37(2)$ & 0.810 \\
\hline Fonksiyon & $4.34 \pm 4.94(2)$ & $3.18 \pm 3.44$ (2) & 0.492 \\
\hline Psikolojik & $2.57 \pm 2.98(1)$ & $1.85 \pm 2.23(1)$ & 0.479 \\
\hline Sosyal etkileşim & $2.19 \pm 2.78(0.5)$ & $0.91 \pm 1.79(0)$ & $0.007^{\star *}$ \\
\hline Ailesel Sıkıntı & $4.07 \pm 2.68(4)$ & $3.74 \pm 2.74$ (4) & 0.551 \\
\hline Aile Fonksiyonu & $0.80 \pm 1.74(0)$ & $1.21 \pm 1.77(0)$ & 0.143 \\
\hline ECOHIS-Skor & $15.76 \pm 12.13(14.5)$ & $12.58 \pm 9.95(11)$ & 0.214 \\
\hline
\end{tabular}

\section{TARTIŞMA}

Son yıllarda ağız sağlığı problemlerinin bireylerin fiziksel, zihinsel ve sosyal sağlığı ve refahı üzerindeki etkisini değerlendirmek için çok sayıda araç geliştirilmiştir. ${ }^{14,15,20} \mathrm{Bu}$ araçlar, insanların hem tedavi edilen, hem de tedavi edilmeyen sağlık ve hastalık durumlarıyla öznel deneyimlerini değerlendirmeye önem vermektedir. ${ }^{4}$ Bu araçlar, diş hekimliği içindeki bir durumu, mevcut ortamından bağımsız olarak gören mekanik bakıştan ziyade, daha bütünsel bir sağlık modelini yansıtmaktadırlar. ${ }^{5}$

Yetişkin ve çocuklar için OHRQoL kavramını anlamak önemlidir. Özellikle çocuklar için, farklı yaş gruplarına göre algıyı değerlendirmek ve ebeveynlerinkinden ayırt edebilmek amacıyla okul öncesi yaş grubu ayrı ele alınmıştır. Son zamanlarda geliştirilen bir dizi araçta ebeveynler için uygun bir teknik ile uygulanan anketlerin, çocukları OHRQoL'si hakkında geçerli ve güvenilir bilgiler üretebileceği sonucuna varıłışstır. ${ }^{14}$ Bu araçlardan biri olan ECOHIS'in, gelişim düzeyindeki tam olgunlaşmama hali nedeniyle okul öncesi çocuklar için, velilerden alınan yanıtları dikkate aldığı, OHRQoL'yi değerlendirmede daha net bilgi verebileceği düşüncesiyle tasarlandığı bildirilmiştir. ${ }^{6}$

Çocuk hastalarda, etkilenen veya kaybedilen diş sayısı artıkça, hastanın yaşam kalitesi üzerindeki olumsuz etkinin de arttığı gözlenmiştir. Diş çürüklerinin çocuklar üzerinde fonksiyonel, psikolojik ve sosyal pek çok etkisi bulunmaktadır. Örneğin; çiğneme ve konuşma bozukluğu (fonksiyonel), okul öncesi devamsızlık, uyku sorunu ve sinirlilik (psikolojik), gülümseme ve konuşmadan kaçınma (sosyal) gibi etkilerin yanı sıra okul performansının düşmesi de bu olumsuz etkiler arasında sayılabilmektedir. ${ }^{12}$ Çocukların ağız sağlığının, genel sağlıkları ve refahları için önemli olduğu pek çok yayında bildirilmiştir. ${ }^{7,14,20}$ Bu nedenle, okul öncesi dönemde bir sağlık problemi olan ve sonraki yaşlarda risk oluşturan ECC'nin mümkün olduğunca önlenmesi ve erken tedavi edilmesi 
gereklidir.

Bu çalışmada, 'fonksiyon belirteci' olan 'Diş problemleri nedeniyle çocuğunuz hiç anaokulu, kreş veya okulu kaçırmış mıdır?' sorusuna verilen 'nadir, ara sıra, sık sık ve çok sık' yanıtları (\% 21.97) 4 ve 5 yaş grubu çocuklar için çoğunluktaydı. Daha düşük yaş gruplarının tamamına yakın kısmından 'hiç' yanıtı (\% 78.3) alınmıştı. Bunun nedeni olarak okul öncesi erken yaş döneminde herhangi bir okula gitmeme durumu düşünülmüştür, ancak çocukların okula ya da kreşe gidip gitmediklerine dair sorunun sorulmamış olması, bu çalışmanın limitasyonudur. 4 yaş sonrasında kreş/ anaokulu gibi okula gitme durumunun olduğu kanısına varılmıştır. Ayrıca, aile fonksiyon belirteci olan 'Diş tedavileri için siz veya başka aile bireyi işten izin almak zorunda kaldınız?' sorusuna verilen 'hiç' yanıtının \% 58.33 oranı ile çoğunlukta olduğu görülmüştür. Bu durumları destekleyen bir diğer etken ise, anketi yanıtlayan annelerin çoğunlukla (\% 75) ev hanımı olması ve çocuğuna kendi bakması olarak kabul edilmiştir.

Ankette, aileyle ilgili olan sorularda 'ebeveyn belirteci' olarak kabul edilen 'Siz veya başka bir aile üyesi çocuğunuzun diş problemleri-diş tedavisi nedeniyle ne sıklıkla üzgün/suçlu hissettiniz mi?' sorularına verilen yanıtlarda üzgün hisseden ebeveynlerin genellikle suçlu da hissettiği görülmüştür. Ancak üzgün hissedip suçlu hissetmeyen (\% 35.61) veliler de vardır, bunun nedeni olarak konunun öneminin veliler tarafından iyi bilinmemesi ve farkındalık eksikliği düşünülmüştür. Bu nedenle ağız ve diş sağlığı hakkında bilgi verme, bilinçlendirme ve farkındalık yaratma açısından, sağlık ve eğitim sistemi alanlarında çalışmalar yapılmasının yararlı olacağı düşünülmektedir.

Aile fonksiyon belirteci olan 'Çocuğunuz diş problemleri veya diş tedavileri ailenize finansal zorluk yaşatmış mıdır?' sorusuna verilen 'hiç' yanıtının çok olmasının (\% 73.48) nedeni olarak, tedavilerin devlet üniversitesinde yapılmış olması ve Sosyal Güvenlik Kurumu tarafından karşılanmış olması düşünülmüştür. Bu sonuç, Yoruldu' nun çalışması ile uyumlu bulunmuştur. ${ }^{21}$ Finansal zorluk yaşadığını düşünen velilerin çocuklarına, yer tutucu gibi laboratuvar masrafları gerektiren farklı tedaviler uygulandığı anlaşılmıştır.

Diş çürüğünün yanı sıra TDY de, okul öncesi çocuklarda yaygın bir ağız içi bozukluk olup yaşam kalitesini etkileyebilmektedir. Bu dönemde çocuk emeklemeyi, ayakta durmayı, yürümeyi ve koşmayı öğrenmektedir. Reflekslerin gelişiminin temel aşaması ve motor koordinasyonun eksikliği düşmelere neden olabilmektedir. Bu durum, TDY sıklığını arttırmaktadır. Bu yaralanma, fiziksel düzeyde üzücü bir deneyimdir, ancak duygusal ve psikolojik düzeylerde de bir etkisi olabilmektedir. Ek olarak, ağrıya, fonksiyon kaybına neden olabilmekte ve gelişmekte olan okluzyonu ve estetiği olumsuz etkileyebilmektedir. Bu durumların, çocukların yaşamları üzerinde olumsuz bir etkisi olabileceği belirtilmiştir. ${ }^{12}$

Siqueira ve ark., diş çürüğü ve ağrı geçmişinin aile alanına negatif etki ettiğini, TDY'nin ise okul öncesi çocuklar ve ailelerinin OHRQoL'si üzerine olumsuz etkisi olmadığını belirtmişlerdir. ${ }^{22} \mathrm{Bu}$ çalışmada ise, diş çürüğünün OHRQoL, semptom, fonksiyon, psikoloji, ailesel sıkıntı ve aile fonksiyonu alanları üzerinde olumsuz etkisi olduğu bulunmuştur. TDY, semptomlar açısından daha olumsuz etki göstermekle beraber, ön bölge maloklüzyon özellikleri, sadece sosyal etkileşim alanı (gülümsemekten, gülmekten, konuşmaktan kaçınma) üzerine negatif etki göstermiştir. Bu etkinin, ön bölge için duyulan estetik kaygıdan kaynaklandığı düşünülmüştür.

Martins-Júnior ve ark. diş çürüğü olan çocukların, çürük olmayan çocuklardan daha yüksek ortalama ECOHIS skorlarına sahip olduğunu bildirmişlerdir. ${ }^{23}$ Mevcut bulgular, bu çalışma ile uyumlu olmakla beraber, ECC'nin bir toplum sorunu olduğunu ve önleyici tedbirlerin alınması gerektiğini düşünmekteyiz.

Aldrigui ve ark. yaptıkları çalışmada, sadece komplike TDY'nin okul öncesi dönemindeki çocuklar ve velileri üzerinde OHRQoL açısından olumsuz etkisi olduğunu ancak ön bölge maloklüzyon özelliklerinin böyle bir etkisi olmadığını belirtmişlerdir. ${ }^{12} \mathrm{Bu}$ çalışmada ise, ön bölge maloklüzyon özellikleri sadece sosyal etkileşim alanı üzerine olumsuz etki göstermiştir. Çalışmalardaki farklılığın, dahil edilen hastaların popülasyon ve kültür farklıığından kaynaklandığı düşünülmüştür.

Çocukların, travma sonrası gülümsemekten kaçınması nedeniyle, TDY'nin sosyal alanı olumsuz etkilediği belirtilmiştir. ${ }^{24}$ Bendo ve ark. Çocuk Algı Anketi (CPQ11-14) kullanarak yaptıkları çalışmada, 11-14 yaş arası çocuklarda, tedavi edilen ve tedavi edilmeyen TDY ile toplam CPQ11-14 değerleri arasında istatistiksel olarak anlamlı bir fark olmadığını, ancak ön bölgede TDY tedavi edilmediğinde, çocuğun gülme gibi sosyal etkileşim durumları açısından olumsuz etkilendiğini belirtmişlerdir. ${ }^{4}$ Çalışmaya dahil edilen popülasyonun yaş grubu farklı olmasına rağmen, ön bölgede görülen TDY ve sosyal etkileşim alanına olan olumsuz etki, bu çalışma ile de uyumludur.

Bani ve ark., TDY sonrası 7-15 yaş arası çocukların ailelerinin OHRQoL'si üzerine etkileri araştırdıkları çalışmalarında, aile etki ölçeği skorlarının, velilerin yaşam kalitesini negatif etkileyecek şekilde değiştiğini belirtmişlerdir. Ebeveyn duyguları en fazla olmak üzere sırasıyla ebeveyn / aile etkinliği, mali yük ve aile çatışması konularında ebeveynlerin yaşam kalitesi üzerinde TDY'nin olumsuz etkisi olduğu bildirilmiştir. ${ }^{25}$ $\mathrm{Bu}$ çalışmada ise, TDY açısından aile üzerinde istatistiksel anlamlı negatif etki görülmezken, diş çürüğünün ailesel sıkıntı ve aile fonksiyonu alanları 
üzerinde olumsuz bir etki gösterdiği bulunmuştur. Bu farklılı̆ın, yaş aralığından ve velilerin süt dişlenme dönemine dair bilinç ve önemseme düzeyinden kaynaklandığı düşünülmektedir. Okul öncesi döneminde, süt dişlerinin geçici olup düşeceği kanısının hakim olduğu toplumumuzda, var olan bir çürük, diş travması problem olarak görülmemekte, çoğu kez bunun için çocuklar diş hekimine götürülmemekte, götürülse bile tedavi istenmeyebilmektedir. Yaş arttıkça, hem hastalarda hem velilerde estetik kaygı artmakta, buna bağlı olarak TDY'ye ve çürüğe bağlı tedavi maliyetleri de artmaktadır.

Sakaryalı ve ark. 1-6 yaş arası okul öncesi çağı çocuklarda yaptıkları çalışmada, ECC, TDY ve maloklüzyon varlığının, bu populasyon ve ailelerinin OHRQoL'si üzerine negatif etkileri olduğunu belirtmişlerdir. OHRQoL'nin arttırıması için, ebeveynlerin ve çocukların farkındalığının arttırıması ve ağız sağlığı ile ilgili halk sağlığı programlarının yapılması gerektiğini vurgulamışlardır. ${ }^{26}$ Bu bulgular, bizim çalışmamı ile de uyumludur ve vurgulanan görüşler desteklenmektedir.

TDY'nin ağız sağlığı ile ilişkili yaşam kalitesine etkisini inceleyen bir metaanalizde, konuyla ilgili yapılan çalışmalar değerlendirilmiştir. TDY'nin okul öncesi çocukların OHRQoL'sini olumsuz etkilediği belirtilmiş, mevcut bulgular ışığında erken çocukluk döneminde TDY'yi önlemek gerektiği ve tedavi programlarına duyulan ihtiyaç vurgulanmıştır. ${ }^{27}$

Vieira-Andrade ve arkadaşlarının okul öncesi çocuklar üzerinde yaptıkları bir olgu kontrol çalışmasında, TDY'nin OHRQoL üzerine etkisi olmadığını belirtmiş; bunun muhtemel nedeni olarak farklı örneklem, yaş aralığı ve yöntemlerin kullanılması gösterilmiştir. Kesitsel çalışmalarda ise TDY'nin OHRQoL'yi etkilediği belirtilmiştir. $^{28}$

Gomes ve ark., okul öncesi dönemi çocukları ile yaptıkları kesitsel bir çalışmada, kavitasyonlu çürük lezyonları ve TDY'nin OHRQoL üzerine etkisi olduğunu belirtmişlerdir. Gomes ve ark. çürük derecesini değerlendirmek amacıyla Uluslararası Çürük Tespit ve Değerlendirme Sistemi (ICDAS II) kullanmışlardır, bu çalışmada ise dmft indeksi kullanılmıştır. ${ }^{19}$ Mevcut konuda, farklı çalışmalarda tek tip çürük tespit sınıflandırımasının olmaması ve popülasyon farklılıklarının mevcudiyeti, farklı sonuçlar elde edilmesine yol açmıştır.

Kramer ve ark. yaptıkları çalışmada, OHRQoL üzerine herhangi bir etki bulunmasının, diş çürüğüne sahip çocuklarda, çürüksüz çocuklara göre üç kat fazla görüldüğünü; TDY ve maloklüzyon için ise bu durumun yaklaşık 1,5 kat fazla görüldüğünü belirtmişlerdir. Ağız hastalığı bulunan çocuklarda ve aileleri/bakıcılarında, yaşam kalitesinin kötü etkilendiği, ağız sağığı politikalarının yaygın risk yaklaşımına dayalı genel sağlık politikalarına dahil edilmesi gerektiği vurgulanmıştır. ${ }^{29}$ Yapılan çalışmalarda farklı görüşler olmakla beraber, bunların uygulanan ülke, bölge ve popülasyonun farklıııklarından kaynaklanabileceği ve yaşam kalitesi üzerinde olumsuz etki gösteren faktörlerin dikkate alınarak sağlık hizmeti sağlanması gerektiği belirtilmiştir. ${ }^{30}$

Bu görüşleri desteklemekle birlikte, ağız ve diş sağlığı hakkında küçük yaşlardan itibaren bilinçlenmenin arttırıması, hasta ve velilerinin TDY konusunda bilgilendirilmesinin, konuyla ilgili eğitimlerin ve kamu spotlarının yaygınlaştıııması gerektiği düşüncesindeyiz.

\section{SONUÇ}

Mevcut sonuçlar ve çalışmalar göstermiştir ki, yaşam kalitesi ile ilgili çalışmaların yöntemlerinin farklı olması, konu açısından farklı sonuçlar oluşturmaktadır. Kullanılan ölçek, çalışma dizaynı ve çürük teşhisinde kullanılan sistem farklı̆ı̆ı ile populasyon ve yaş aralıklarının aynı olmaması limitasyon oluşturmaktadır. Daha güvenilir sonuçlar için, yöntemlerde standardizasyon sağlanması yararlı olacaktır. Ancak, ortak paydada düşünülen, sağlık programlarına ağız hastalıklarının da dahil edilip, etkili bir koruyucu program uygulanmasıdır.

TDY ve maloklüzyonlar, okul öncesi çocukların OHRQoL'si üzerinde olumsuz bir etkiye sahiptir; ancak, diş çürüğü, okul öncesi çocukların ve onların ebeveynlerinin OHRQoL'si ile güçlü bir ilişkiye sahiptir. Çocukların fiziksel, sosyal, psikolojik, fonksiyonel ve estetik refahlarını değiştirebilecek bu ağız içi bozuklukların iyi anlaşıması, ağız sağlığının yanı sıra genel sağlığı da olumlu yönde etkileyecektir. Erken yaşta alınan önlemler, çocukların ilerleyen dönemlerdeki ve yetişkinlikteki yaşam kalitesini arttıracaktır. 


\section{KAYNAKLAR}

1. Chen M, Feng ZC, Liu X, Li ZM, Cai B, Wang DW. Impact of malocclusion on oral health-related quality of life in young adults. Angle Orthod 2015;85(6):986-91.

2. Allen PF. Assessment of oral health related quality of life. Health Qual Life Outcomes 2003;1:1-8.

3. Kressin N, Spiro A, Bosse R, Garcia R, Kazis L. Assessing Oral Health-Related Quality of Life Findings from the Normative Aging Study. Med Care 1996;34 (5):416-427.

4. Bendo CB, Paiva SM, Torres CS, Oliveira AC, Goursand D, Pordeus IA et al. Association between treated/untreated traumatic dental injuries and impact on quality of life of Brazilian schoolchildren. Health Qual Life Outcomes 2010;8:114.

5. Pahel BT, Rozier RG, Slade GD. Parental perceptions of children's oral health: the Early Childhood Oral Health Impact Scale (ECOHIS). Health Qual Life Outcomes 2007;5:6.

6. Gediz M, Yetkiner E, Ersin N. Çocuk diş hekimliği ve yaşam kalitesi üzerindeki etkileri "ortodonti”. Ertuğrul $F$, editör. Çocuk Diş Hekimliği ve Yaşam Kalitesi Üzerindeki Etkileri. Türkiye Klinikleri 2019;(1):27-34.

7. Sischo L, Broder HL. Oral Health-related Quality of Life: What, Why, How, and Future Implications. J Dent Res 2011; 90(11):1264-1270.

8. Bönecker M, Abanto J, Tello G, Oliveira LB. Impact of dental caries on preschool children's quality of life: an update*. Braz Oral Res 2012;26(1):103-7.

9. Policy on Early Childhood Caries (ECC): Classifications, Consequences, and Preventive Strategies. AAPD Oral Health Policies, The Reference Manuel of Pediatric Dentistry, Latest Version 2016.

10. Oubenyahya H, Bouhabba N. General anesthesia in the management of early childhood caries: an overview. J Dent Anesth Pain Med 2019; 19(6): 313322.

11. Abanto J, Carvalho TS, Mendes FM, Wanderley MT, Bönecker M, Raggio DP. Impact of oral diseases and disorders on oral health-related quality of life of preschool children. Community Dent Oral Epidemiol 2011; 39(2):105-14.

12. Aldrigui JM, Abanto J, Carvalho TS, Mendes FM, Wanderley MT, Bönecker M, Raggio DP. Impact of traumatic dental injuries and malocclusions on quality of life of young children. Health Qual Life Outcomes 2011;24(9):78.

13. Milani A, J, Fonseca Alves N, Martins do EspirotoSanto T, Gonçalves Ribeiro L, Ammari M, M, Antunes L, S, Alves Antunes L, A: Impact of Traumatic Dental Injuries on Oral Health-Related Quality of Life of Preschool Children and Their Families Attending a Dental Trauma Care Program. Port J Public Health 2019;37:19-25.

14.Juniper EF, Guyatt GH, Jaeschke R: How to develop and validate a new health-related quality of life instrument. In: Quality of Life and Pharmacoeconomics in Clinical Trials Edited by: Spilker B. Philadelphia: Lippincott-Raven Publishers, 1996.
15.Guyatt GH, Feeny DH, Patrick DL: Measuring health-related quality of life. Ann Intern Med 1993;118:622-629.

16.DeVellis R. Scale development, In: Theory and applications, 2nd edn. New York: Sage Publications Inc, 2003.

17.Peker K, Uysal O, Bermek G. Cross-cultural adaptation and preliminary validation of the Turkish version of the early childhood oral health impact scale among 5-6-year-old children. Health Qual Life Outcomes 2011; 9:118.

18. Andreasen JO, Andreasen FM, Andersson L. Textbook and color atlas of traumatic injuries to the teeth Copenhagen: Munskgaard, 2007.

19. Gomes MC, Pinto-Sarmento TC, Costa EM, Martins CC, Granville-Garcia AF, Paiva SM. Impact of oral health conditions on the quality of life of preschool children and their families: a cross-sectional study. Health Qual Life Outcomes. 2014;12(1):55.

20. Slade GD. Measuring oral health and quality of life. Chapel Hill, Department of Dental Ecology, School of Dentistry, University of North Carolina; 1997:160.

21.Yoruldu S. Erken Çocukluk Dönemi Çürüğü ve Sonuçlarının Çocukların Yaşam Kalitesine Etkisi. [thesis]. İzmir: Ege University; 2013.

22. Siqueira MB, Firmino RT, Clementino MA, Martins CC, Granville-Garcia AF, Paiva SM. Impact of traumatic dental injury on the quality of life of Brazilian preschool children. Int $\mathrm{J}$ Environ Res Public Health 2013;10(12): 6422-41.

23. Martins-Júnior PA, Ramos-Jorge J, Paiva SM, Marques LS, Ramos-Jorge ML. Validations of the Brazilian version of the Early Childhood Oral Health Impact Scale (ECOHIS). Cad Saude Publica 2012;28(2):367-74.

24. Çehreli SB, Çehreli ZC. Travmatik dental yaralanmaların çocukların yaşam kalitesi üzerine etkileri. Ertuğrul F, editör. Çocuk Diş Hekimliği ve Yaşam Kalitesi Üzerindeki Etkileri. Türkiye Klinikleri 2019;(1):13-9.

25.Bani M, Alaçam A, Çınar Ç. How Does Dental Trauma Affect the Quality of Life in Turkish Families? Oral Health Prev Dent 2017;15(6): 563-7.

26. Sakaryali D, Bani M, Cinar C, Alacam A. Evaluation of the impact of early childhood caries, traumatic dental injury, and malocclusion on oral healthRelated quality of life for Turkish preschool children and families. Niger J Clin Pract 2019;22(6):817-823.

27. Borges TS, Vargas-Ferreira F, Kramer PF, Feldens CA. Impact of traumatic dental injuries on oral health-related quality of life of preschool children: A systematic review and metaanalysis. PLoS One 2017;12(2): e0172235.

28. Vieira-Andrade RG, Siqueira MB, Gomes GB, D'Avila S, Pordeus IA, Paiva SM, et al. Impact of traumatic dental injury on the quality of life of young children: a case-control study. Int Dent $J$ 2015;65(5):261-8. 
29.Kramer PF, Feldens CA, Ferreira SH, Bervian J, Rodrigues $\mathrm{PH}$, Peres MA. Exploring the impact of oral diseases and disorders on quality of life of preschool children. Community Dent Oral Epidemiol 2013;41(4):327-35.

30.Mouradian WE. The face of a child: children's oral health and dental education. J Dent Educ 2001; 65:821-831.

Yazışma Adresi:

Aliye Tuğçe GÜRCAN

Altınbaş Üniversitesi

Diş Hekimliği Fakültesi

Çocuk Diş Hekimliği AD.

İstanbul, Türkiye

Tel : : +902127094528

E Posta: tugcetanyeri@gmail.com 